\title{
THE MINIMUM RATE POWER AND THE CONTROL OF CARRIER COMPETITION
}

\author{
HARVEY C. MANSFIELD $\dagger$
} PON what criteria shall the Interstate Commerce Commission act in
fixing minimum rates, below which a railroad's charge for its service will be regarded as unlawful? Though this question had often been argued before the Commission in the years since 1920, it was not presented to the Supreme Court in a general form until the 1934 term, when it was raised in Youngstown Sheet \& Tube Co. v. United States ${ }^{1}$ and summarily dismissed in a decision that was overshadowed in public interest by the contemporaneous argument and decision of the Schechter case. $^{2}$ The question promises to grow in importance as other forms of transportation, less subject to Commission control, undermine further the monopoly position to which the railroads have until recently been accustomed. The importance of these competing transportation services will focus increasing attention upon the lower instead of the upper lawful limits of the rate structure. ${ }^{3}$ The power to fix minimum prices is the power to protect a vested interest against the consequences of competition, justified in a dynamic society only by a greater public advantage in stability than in change.

Railroad rate structures, so the texts tell us, were built up largely by applying two "principles," the cost of the service to the carrier, and the value of the service to the shipper (or "what the traffic will bear"), both loosely defined concepts at best." Within the broad zone thus defined, the general level of rates on any particular commodity tends toward the lower limit of cost where the shippers have some definite bargaining advantage over the carriers, and toward the top when carriers dominate the market, the common situation historically, but the rarer one today. For many commodities, such as coal, grain, cotton and lumber, the chief problem is to adjust the rival interests of a number of railroads

iAssistant Professor of Government, Yale University.

1. 295 U. S. 476 (1935).

2. 295 U. S. 495 (1935).

3. The standard texts give scant attention to minimum rates except in connection with the removal of discrimination. Lockins, Economncs of Transportatron (1935) 316-317; MIILER, INLANd Transportation (1933) 226-227; RIpley, RaILroads (1927) 625-626; Jones, Princtrles of RaIlway Transportation (1927) 552; Dageetr, Princtiles of Inland Transportation (1934) 846. The best discussion is in 1 Strartaran, Tue Interstate Commarerce Conamission (1931) 197-301, 3B Sharriman, Tue Intenstate Comanerce Comanasston (1936) 626-656; and in Biklé, Power of the Interstale Commerce Commission to Prescribe Minimum Rates (1922) 36 HaRv. L. REv. 5.

4. See texts, supra, note 3. Experience has amply shown that neither carricrs nor shippers act consistently as "economic men" in rate making. 
and a much larger number of shippers, the latter geographically scattered and obliged to sell their product competitively (i.e., at an equalized price) in a few major consuming markets. The typical solution of this problem for the great basic commodities is a rate structure based upon so-called "key-rates" between the consuming centers and each of the major producing areas. Rates to the same markets from other points of origin are determined by adding or subtracting arbitrary amounts, called difierentials, to or from the relevant key rate. Differentials in effect measure the terms upon which shippers outside the principal areas of supply can compete in the principal markets. The adjustment of key rates is primarily a matter of carrier competition; the fixing of differentials more often reflects the rivalries of shippers. Characteristic also of such structures is a blanketing of numerous points of origin and of destination under single rates-a comprorise between the desire for equalization of rates on the postage stamp theory, and the demand of shippers favorably located that their geographical advantages be recognized.

Rate structures of this sort have a high degree of rigidity. The general increases and decreases in rates of the past two decades have been applied to them not in percentages, but in flat amounts of so many cents per ton throughout, so as not to disturb the differential adjustments. Nevertheless, disputes over the fairness of the adjustments are continuous, as shippers or railroads who find themselves losing out, attempt to better their positions. It is lower rates they want, and to the extent they succeed in getting them their competitors are under pressure to do likevise. Every attempt at reduction may therefore be expected to provoke opposition. If the railroads can not, or do not resist the pressure for reductions, inevitable in this situation, and in comparable ones arising in other areas of competition, when, and upon what grounds, should the Commission intervene to exercise its authority to fix minimum rates?

The theory of rate-making assumed that the self-interest of railroads would ordinarily prevent rates from falling below what was described without precision as cost; and the framers of the original Interstate Commerce Act certainly assumed that if such did not always prove to be the case, there was still no occasion for governmental action to save the carriers from their own folly. There was never any doubt that the command in that act that all rates shall be "just and reasonable" was not intended to confer on the commission a power to set minimum rates."

The need for such a power, however, appeared early in the Commission's experience, not only in the inability of the railroads to protect

5. See Arsv. REP. I. C. C., 1858, 19-24; Commiscioner Cooley's able diceussion in Re Chicago, St. P. \& K. C. Ry. Co., 2 I. C. C. 231 (18s8); review by Brandeis, J., in Skinner \& Eddy Corp. v. United States, 249 U. S. 557, 565 (1919). 
themselves against cut-throat competition, but also in the interests of shippers who otherwise had no adequate protection against discrimination. ${ }^{6}$ Other reasons appeared in the course of time but the movement to give the commission a minimum rate power made headway slowly. The Hepburn Act in 1906 cured the defects in the Commission's power to fix maximum rates for the future, ${ }^{7}$ but it was not until the Transportation Act of 1920 that Congress was induced to grant a direct power to fix minimum rates. ${ }^{8}$ The notion that a low rate was not always a good in itself died hard.

It is true that prior to 1920 the Commission had certain indirect means at its disposal for preventing some rate reductions. To correct unlawful rates, as defined in the first four sections of the Act, two principal remedial powers were conferred in addition to the control over maximum rates: first, a power to cure discriminations by ordering a carrier, in the alternative, either to raise a preferential rate or to lower a prejudicial one, or to do both, ${ }^{9}$ and second, a power to suspend proposed rates before they took effect, to be followed by cancellation if they were found to be unlawful. ${ }^{10}$ Both means of control could be used, in effect, to fix minimum rates. ${ }^{11}$ The suspension power, in particular, has been, and still is a potent weapon for achieving that end. When proposed rates are suspended the burden is placed upon the carrier to justify them. ${ }^{12}$ The suspension and cancellation of proposed reductions operates as a minimum order, especially when a proviso is added to the Commission's order, that "this is without prejudice to the filing of rates not lower than those specified in the report herein." The increase in carrier competition since 1920 is strikingly evident in the corresponding increase in the number of reductions suspended and cancelled, as shown in the following table:

6. See Ann. Rep. I. C. C., 1893, 38-39, 217-225; id., 1898, 23, 26; Harlan, Commr,, dissenting in Western Rate Advance Case, 35 I. C. C. 497, 681 (1915); Galloway Coal Co. v. Alabama G. S. Rr. Co., 40 I. C. C. 311, 315 (1916); Hearings on Extension of Tenure of Government Control of Railroads, 65th Cong., 3d Sess. (1919) 234.

This inability to control discrimination effectively resulted from a doctrine known as the Ashland rule. See note 21 infra.

7. 34 Stat. 589 (1906), 49 U. S. C. A. \& 15 (1) (1926).

8. 41 Stat. 484 (1920), 49 U. S. C. A. \& 15 (1) (1926).

9. 24 Stat. 384 (1887), 34 Stat. 589 (1906); 36 Stat. 551 (1910), 49 U. S. C. A. $\S 15$ (1) (1926).

10. 36 Stat. 552 (1910), 49 U. S. C. A. \& 15 (7) (1926) (The Mann-Elkins Act).

11. For an early example see Suspension of Rates on Packing House Products, 21 I. C. C. 68 (1911). Instances since 1920 of reductions suspended and cancelled without specifically invoking the minimum rate power are numerous, e. 'g., Lake Cargo Coal from Kentucky, 139 I. C. C. 367 (1928); Coal from Illinois to Keokuk, Iowa, 210 I. C. C. 395 (1935).

12. By contrast the burden of proving unlawfulness in established rates rested on the complainant, or on the Commission, if the proceedings were begun on its own motion. 
Suspensions of Proposed Rates Requested of the I. C. C.13

$\begin{array}{lccccc}\text { Year } & \text { Increases } & \text { Reductions } & \text { Both } & \text { Neither } & \text { Total } \\ 1921 & 401 & 43 & - & - & 444 \\ 1926 & 560 & 83 & - & - & 643 \\ 1931 & 228 & 125 & 60 & 26 & 439 \\ 1932 & 278 & 253 & 73 & 22 & 626 \\ 1933 & 172 & 245 & 25 & 19 & 461 \\ 1934 & 178 & 201 & 34 & 20 & 433 \\ 1935 & 194 & 123 & 34 & 1 & 352\end{array}$

Thus, even in the face of two major efforts to raise the general level of freight rates during the depression years, ${ }^{14}$ localized reductions have been offered right and left, for, reduced rail traffic means reduced railroad bargaining power. And in granting or refusing these reductions, the Commission must formulate its criteria for fixing minimum rates.

Similarly, the control of rates under the long-and-short-haul clause involves the setting of minima..$^{15}$ The Commission has discretionary power to grant or deny relief from the fourth Section. ${ }^{10}$ When relief is denied, the minimum charge for the long haul is thereby set at the level of the maximum for any intermediate haul. ${ }^{17}$ When relief is granted, the degree of the departure allowed again fixes a minimum for the long haul. Here again, there has been a significant increase in the number of applications for fourth Section relief, and a glance at the current volumes of the Commission's reports indicates that continued increases are likely

13. ANN. REP. I. C. C., for the years given, pp. 39, $45,65,85,71,75,91$, respeclively.

14. Fifteen Per Cent Case, 1931, 178 I. C. C. 539 (1931), 179 I. C. C. 215 (1931), 191 I. C. C. 361 (1933); Emergency Freight Charges, 1935, 203 I. C. C. 4 (1935). A united request of large shippers' organizations for a general Yeduction in all freight rates was also denied. General Rate Level Investigation, 1933, 195 I. C. C. 5 (1933).

15. 24 Stat. 380 (1887), 49 U. S. C. A. $\$ 4$ (1) (1926). For examples of minimum rates fixed by setting limits to permitted departures from fourth section, sse Commodity Rates to Pacific Coast Terminals, 32 I. C. C. 611, 629 (1915); Sugar Cases of 1933, 195 I. C. C. 127 (1933); Export and Import Rates to and from Southern Ports, 205 I. C. C. 511 (1935), modified 210 I. C. C. 525 (1935); Rates from and to Pacific Coast Territory 210 I. C. C. 575 (1935); Sugar from California to Chicago, 211 I. C. C. 239 (1935).

16. Railroad Commission of Nevada v. Southern Pacific Co., 21 I. C. C. 329 (1911), aff'd, Intermountain Rate Cases, 234 U. S. 476 (1914).

17. For instances of reductions denied because they would violate this section, see Transcontinental Cases of 1922, 74 I. C. C. 48 (1922); Coffee from New Orleans, 182 I. C. C. 453 (1932).

Another deterrent to reductions, which may operate to fis minims, is found in $\S 4$ (2), that if a railroad reduces a rate on account of water competition, the rate may not thereafter be raised except upon some change in conditions other than the elimination of the water competition. This was to prevent railroads from reducing rates dratically for a temporary period in order to drive a water carrier out of business. 
unless the current effort to repeal the long-and-short-haul clause should prove successful. ${ }^{18}$

Again, in exercising control over intrastate rates under the Shreveport doctrine, ${ }^{19}$ later written into the Transportation Act as Section 13, the Commission has acted, mainly on grounds of discrimination, to set the interstate level as a minimum for intrastate rates. ${ }^{20}$ Finally, in putting into effect, a Commission order enforcing the prohibition in Section 3 against undue preference and prejudice, the carrier often found, even when an alternative order was issued, that in practice it had to raise the preferred rate to the level of the one that occasioned the prejudice, which thereupon became the minimum.

It was in the effort to cure discrimination, however, that the want of a direct power to fix minimum rates was most acutely felt by the Commission. In Ashland Fire Brick Co. v. Southern Railway,, Section

18. For the last three years the number of cases in which the Fourth Section was involved has averaged 335 annually, of which about four-fifths were decided favorably to the carriers. ANN. RER. I. C. C. (1933) 72 ; id. 1934, at 76; id. 1935, at 92 . The figures are about double those of ten years previous.

A bill to repeal the Fourth Section was introduced by Rep. Pettengill, with the backing of railway managements and labor, and passed the House this spring. It was opposed by the Commission and did not emerge from the Senate Interstate Commerce Committco during this session. For a comprehensive discussion of the Fourth Section, sce Comment (1936) 45 YALE L. J. 1426.

19. Houston, E. \& W. T. Ry. Co. v. United States, 234 U. S. 342 (1914). Note that one of the jokers in the Motor Carrier Act, 49 STAT. 543, 49 U. S. C. A. $\& 302$ (1935), a political concession to aid its passage, expressly repudiated the Shreveport rule, leaving the Commission powerless to raise intrastate motor carrier rates on account of discrimination against interstate commerce, 49 STAT. 559, 49 U. S. C. A. $\$ 316$ (e) (1935). George, The Federal Motor Carrier Act of 1935 (1936) 21 ConN. L. Q. 249, 272.

20. The successive phases of the Commission's administration of this power, and the criteria upon which it has acted are discussed in 2 SHarparan, Interstate Comantrct: Commassion (1931) 269-307, and Comment (1934) 44 YALE I. J. 133. Cf. Ohio v. United States, 292 U. S. 498 (1934); Intrastate Rates on Bituminous Coal in Illinois, 182 I. C. C. 537 (1932). The refusal of state commissions to follow the Commission's action in Emcrgency Freight Charges, 208 I. C. C. 4 (1935) has led to another series of cases, The stato commissions were upheld in Emergency Freight Charges, 210 I. C. C. 289 (1935) (Minnesota); 210 I. C. C. 541 (1935) (Indiana); 211 I. C. C. 23 (1935) (Oklahoma); 211 I. C. C. 219 (1935) (Arkansas); 211 I. C. C. 225 (1935) (Kansas); 211 I. C. C. 499 (1935) (Louisiana); 213 I. C. C. 130 (1935) (Idaho). But in 213 I. C. C. 249 (1935) (Utah); 213 I. C. C. 563 (1936) (Georgia), and 214 I. C. C. 129 (1936) (Minnesota), the surcharges were imposed, the last mentioned case reversing the previous year's decision. Some of the Minnesota surcharges were given up, on the carriers' motion, as soon as they were obtained, to avoid loss of traffic to trucks. 215 I. C. C. 314 (1936).

21. 22 I. C. C. 115 (1911); Texas \& Pacific Ry, Co. v. United States, 289. U. S. 627 (1933); cf. Eau Claire Board of Trade v. Chicago, M. \& St. P. Ry. Co., 5 I. C. C. 264 (1892); 3B Starfaran, op. cit. stipra note 3, at 636-650; Lockins, op. cit. stipra note 3, at 527; Comment (1933) 43 YALE L. J. 297; Comment (1936) 45 YALE L. J. 692. In the principal case the Southern Ry., participating in hauls from Ashland, $\mathrm{Ky}$., and from St. Louis to a common market in Birmingham, Ala., was held not liable under $\$ 3$ for 
$3 \mathrm{had}$ been interpreted so as to fit the definition of what could be regarded as unlawful discrimination to the character of the remedies then available to the Commission. Under that rule a difference in rates for similar service to shippers from two different points to the same destination was not unlawful unless the same carrier or carriers participated in the service to both, and unless the carriers could be held individually responsible for the discrimination, in the sense that it was possible for them to remove it by their own acts. If the discrimination resulted from the independent action of different carriers, then the shipper or locality was left without a remedy, even as against a carrier which participated in both rates but could control neither. The reason for this rule lay in the fact that the Commission had no power to raise the rates of the independent carrier to the preferred locality, nor could it reduce a reasonable rate to the prejudiced locality. ${ }^{22}$ And a carrier serving both points could not remove the discrimination by any act of its own so long as the independent rate to the preferred locality remained. It must seem an irrelevant question to the shipper suffering under a high rate, whether or not the carriers serving both him and his more generously treated competitor are under common control; but upon this fortuitous circumstance the Commission's ability to help him then depended. Thus the absence of the minimum rate power controlled the substantive definition of what unlawful discrimination was. The recognition of this limitation was one of the grounds originally urged by the Commission for the granting of the minimum rate power. ${ }^{6}$

It is somewhat anomalous that the legislative history of the Transportation Act gives little clue to the purposes Congress desired to serve when it conferred the power to fix minimum rates on the Commission. The prevention of rate wars, the removal of non-compensatory rates, and the protection of weaker water carriers from ruthless railroads were mentioned in the committee reports; it is not clear what other considerations were thought of. ${ }^{23}$ Discrimination by low intrastate rates, the practice common to trunk lines of forcing high divisions of joint rates from their short-line connections, and the protection of a rate

prejudice to Ashland on the ground that independent carriers served both points, and since the Commission could not raise the rate from St. Louis, the Southern could not cure the discrimination by any act of its own, either by adjusting its rates or by withdrawing from the business.

22. Galloway Coal Co. v. Alabama G. S. Rr. Co., 40 I. C. C. 311,315 (1916).

23. Return of Railroads to Private Ownership, House Repont, No. 456, 66th Cong., 1st Sess. (1919), 10, 19, and remarks of Rep. Esch, 58 Cosc. Rec 8654 (1919). Senator Cummins briefly mentioned the power on the floor as an aid to weal: connecting lines in securing fair divisions of joint rates, 59 CoNG. REC. 141 (1919); but that purpose was adequately served by $\S 15$ (6), New England Divisions Case, 261 U. S. 184 (1923). Other incidental references to the power in the course of debate will be found in 59 Coxc. Rec. 364-5, 468, 745 (1919). 
structure designed to provide an adequate revenue, had been urged as reasons why Congress should give the Commission the minimum rate power. ${ }^{24}$ But other sections of the Transportation Act dealt expressly with these problems. ${ }^{25}$ No mention was made in Congress of the possible effect of the grant of the power to fix minimum rates on the Ashland rule, although that rule was responsible for the largest gap in the Commission's control of railroad rate discrimination.

In the interpretation of the minimum rate power, the Commission was soon confronted by the question of whether this new grant of additional power effected a tacit repeal of the $A$ shland rule. For, although a finding of discrimination provides a clearly appropriate basis for a minimum rate order, such a finding can be made only if a violation of Section 3 is found to exist. Therefore, unless the grant of the minimum rate power provided a new basis for a finding of discrimination under Section 3 by abrogating the Ashland rule, it could not serve to close the gaps in the Commission's control of discrimination. Valid grounds for holding that this limitation should no longer be effective could have been inferred from the terms of the statute, which seem clear and sweeping. Section 15 (1) provides: ${ }^{26}$

"Whenever ... the Commission shall be of opinion that any . .
rate ... is or will be ... unduly preferential or prejudicial ... the
Commission is hereby authorized and empowered to determine and
prescribe what will be the just and reasonable individual or joint rate,
fare, charge, or rates, fares, or charges, to be thereafter observed in
such case, or the maximum or minimum, or maximum and minimum,
to be charged . and to make an order that the carrier or carriers
shall cease and desist from such violation ... and shall not thereafter
publish ... . any rate ... less than the minimum so prescribed. ..."

If the Commission finds a discrimination in the rates from two points to the same destination, why can it not by a minimum rate order raise the rate from the preferred locality offered by any independent carrier from that point? If that were done, the ground for exempting any other carriers participating in the discrimination would disappear. And with the removal of the reason for the Ashland rule, the rule itself might be repudiated. On the other hand, if the origin of the rule were forgotten, then it might be said that the Transportation Act altered only the remedies available, and not the definition of discrimination in Section 3. In that case, preference and prejudice are still not "undue," so as to justify a minimum rate order, unless responsibility can be placed upon individual carriers.

24. Biklé, loc. cit. supra note 3 .

25. 41 STAT. $484,486,488-91$ (1920), 49 U. S. C. A. $\S \S 13$ (4), 15 (6), 15a (2) (1926).

26. 41 STAT. 485 (1920), 49 U. S. C. A. \& 15 (1) (1926). 
The Commission at first adhered to the Ashland rule; ${ }^{27}$ then at the behest of counsel for shippers in numerous cases and with apparent encouragement from the Supreme Court, ${ }^{28}$ a majority moved gradually to the more literal, and broader, interpretation of the Act.9 ${ }^{=9}$ But when a clear test case arose, the Commission was sharply told by the Supreme Court in a five-to-four decision that the Ashland rule was still the law.9 The result has been, therefore, that the minimum rate power has given the commission a new remedy in its control of discrimination, but has not affected the underlying definitions which condition the Commission's power in this field. ${ }^{31}$ One practical effect of the power to fix minimum rates upon the Commission's ability to control discrimination

27. Sugar Cases of 1922, 81 I. C. C. 448 (1923); Miaritime Ass'n of Boston Chamber of Commerce v. Ann Arbor Rr. Co., 95 I. C. C. 539 (1925); Lake Cargo Coal Rates, 1925, 101 I. C. C. 513 (1925); Galveston Commercial Ass'n v. Galveston, H. \& S. A. Ry. Co., 128 I. C. C. 349 (1927); Baltimore Chamber of Commerce v. Ann Arbor Rr. Co., 159 I. C. C. 691 (1929).

28. The first case touching on the subject after the Transportation Act seemed to negative any assumption of a change in § 3. "Carriers," said Mrr. Justice Brandeis in Central Rr. Co. of N. J. v. United States, 257 U. S. 247, 259 (1922), "can be held . . . responsible for unjust discrimination only if each carrier has participated in some way in that which causes the unjust discrimination. . . . What Congress sought to prevent by that section, as originally enacted, was not differences between localities in transportation rates, . . but unjust discrimination between them by the same carrier or carriers. Neither the Transportation Act, 1920, . . nor any earlier amendatory legislation bas changed, in this respect, the purpose or scope of sec. 3." But two years later he spole differently: "For now, the interests of the individual carrier must yield in many respects to the public need ... and the newly conferred power to grant relief against rates unreasonably low may afford protection against injurious rate policies of a competitor, which were theretofore uncontrollable." United States v. Illinois Central Rr. Co. 263 U. S. 515, 525 (1924). This attitude was continued in United States v. Pennsylvanin Rr. Co., 266 U. S. 191 (1924); Chicago, I. \& L. Ry. Co. v. United States, 270 U. S. 287 (1926); Virginian Ry. Co. v. United States, 272 U. S. 658 (1926), cases dealing mainly with

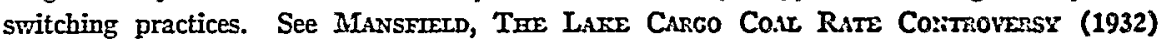
c. 7, and comments cited note 2 supra.

29. Oswego v. Baltimore \& Ohio Rr. Co., 146 I. C. C. 293 (1928), 151 I. C. C. 717 (1929); Duluth Chamber of Commerce v. Chicago \& Northwestern Ry. Co., 156 I. C. C. 156 (1929); Inland Empire Manufacturers' Ass'n v. Abilene \& Southern Ry. Co., 165 I. C. C. 53 (1930); Lake Cargo Coal from Kentucky, 139 I. C. C. 367 (1928). See alca Eastern Class Rate Investigation, 164 I. C. C. 314,416 (1930). But cf. Wisconsin Bridge and Iron Co. v. Hlinois Terminal Co., 161 I. C. C. 176, 179 (1930).

30. Texas and Pacific Ry. Co. v. United States, 289 U. S. 627 (1933), rev'g Galveston Commercial Ass'n v. Galveston, H. S. A. Ry. Co., 160 I. C C. 345 (1929). Mr. Justice Roberts wrote the opinion, with Mr. Justice Brandeis among the dissenters. See also 3B Sharfman, loc. cit. supra note 3.

31. For instances of reductions cancelled because they would violate $\S 3$, see Coal from Detroit, Toledo, and Ironton Rr. Mines, 64 I. C. C. 564 (1921); Rail-and-water Rates from Atlantic Seaboard, 63 I. C. C. 267 (1921); Salt from La. Mines to Chicago, 66 I. C. C. 81 (1922), 69 I. C. C. 312 (1922); Salt from C. F. A. to Western Trunk Line Destinations 74 I. C. C. 409 (1922); Pig Iron from Southern Producing Points, 74 I. C. C. 330 (1922). 
may, however, be observed. Prior to 1920 it was thought necessary that an alternative be allowed the carrier in complying with a Section 3 order: that it must be permitted to elect whether it will raise the preferential rate, or lower the prejudicial one, or strike an intermediate level for both. $^{32}$ A dictum in the Texas and Pacific $R y$. case indicates indeed that such is still the case if the remedial order is merely to "cease and desist" from violating Section $3 .^{33}$ But by proceeding to fix both maximum and minimum at the same point, the Commission may determine the precise level to which both rates must be adjusted. ${ }^{24}$ This is a considerable advantage to the Commission, especially in fixing differentials.

A vaguer basis for using the power to raise rates is found in claims that rates are unreasonably low in violation of Section 1, or too low to provide the revenues necessary to support an "adequate transportation system," as commanded by Section $15 \mathrm{a}^{35}$ It is often impossible to distinguish between these grounds in a decision of the Commission, since an adequate return is one element in determining a "reasonable" rate..$^{30}$ Here the major difficulties in fixing minimum rates emerge. When the Commission reduces a rate because it is unreasonably high, two sorts of evidence are usually considered: the cost of the service, and comparisons with other rates in the same territory or for similar services and under similar transportation conditions, which are regarded as reasonable maxima. These criteria are not readily applicable in fixing minimum rates. In view of the difficulty of apportioning joint costs, and the importance of the volume of traffic that will move at different rate levels, one can seldom be dogmatic in asserting that any particular rate is so low as not to be compensatory. Moreover, there is no large body of rates approved as reasonable minima available for comparative purposes. ${ }^{\text {at }}$

32. Detroit, G. H. \& M. Ry. Co. v. Interstate Commerce Comm., 74 Fed. 803 (C. C. A. 6th, 1896), aff'd 167 U. S. 633 (1897); American Express Co. v. Caldwell, 244 U. S. 617 (1917).

33. 289 U. S. 627,650 (1933).

34. Id. at 650, n. 39.

35. For instances of reductions denied on these grounds, see Salt Cases of 1923, 92 I. C. C. 388 (1924); Oil from Texas Ports, 63 I. C. C. 74 (1921); Coal from Wyoming Mincs, 68 I. C. C. 254 (1922); Lake Cargo Coal from Kentucky, 139 I. C. C. 367 (1928); Trunk Line \& Ex-lake Iron Ore Rates, 69 I. C. C. 589, 610 (1922); Grain \& Grain Products, 115 I. C. C. 153 (1926) ; Lake Cargo Coal from Kentucky, 139 I. C. C. 367 (1928); Cement from Linwood, 140 I. C. C. 579 (1928); Coffee from New Orleans, 182 I. C. C. 453 (1932); Jefferson City and North Jefferson, Mo., Rates, 213 I. C. C. 195 (1935). One of the few cases where existing rates were raised for these reasons, as distinguished from reductions cancelled, is Coal, Bituminous, Ex-river, from Colona and Conway, Pa. to Youngstown, Ohio, 197 I. C. C. 617 (1933) (Third Report), discussed infra.

36. Coal from Illinois to Keokuk, Iowa, 210 I. C. C. 395 (1935); cf. Express Merchandise from Cincinnati, Ohio, to South, 210 I. C. C. 89 (1935), in which the rates proposed were deemed to violate all the crimes in the calendar.

37. 3B Sharfman, op. cit. supra note 3 , at $628-629$ 
Nevertheless, the out-of-pocket cost of a particular service plus some modest contribution to overhead, though not necessarily to profit, is evidently one criterion of action. A finding that a rate is below the costs of the service fairly allocable to it provides the clearest basis for a minimum rate order. Although the Commission has several times repeated that the power should be "sparingly exercised,"333 and only where necessary to avoid "substantial public injury," nevertheless it has based minimum rate orders on such findings in order to prevent the wasteful depletion of carrier revenues, or to stop what might be regarded as a concealed rebate. ${ }^{40}$ Until the Youngstown case, the only minimum rate order challenged in the courts was of this kind, and resulted in an affirmance of the Commission's order. ${ }^{\text {II }}$

A variant of this criterion has been used to justify fixing a minimum on a cost basis by a finding that a rate, though not actually below outof-pocket cost, is still so low that it tends to cause increases in other rates of the same carrier. Such a rate relationship would not amount to a discrimination which could be dealt with under Section 3 unless the commodities, localities, or shippers involved were competitive, but it would result in an inequitable distribution of the burden of filling the carrier's treasury, and on that ground the low rate has been condemned as unreasonable. ${ }^{42}$ This sort of finding necessarily contains subjective elements. Thus, traffic may be classified according to its intrinsic value and volume of movement, justifying a higher carload revenue return from typewriters than from iron ore. ${ }^{43}$ Nevertheless, there can be little quarrel with the use of the minimum rate power to prevent rates so low that they impose a loss on the carrier proposing them, and thus burden its other traffic.

We enter a more doubtful realm, when the minimum rate power is invoked in cases where it is not seriously contended that the rates protested are below the cost of the service. Indeed, Mr. Justice Roberts, in a dictum in the Texas and Pacific $R y$. case, inferred that the power

38. Sugar Cases of 1922, 81 I C C. 448 (1923); Cloverdale Spring Co. v. Atlantic Coast Line Rr. Co., 174 I. C. C. 133, 135 (1931); Iron and Steel Articles, 155 I. C. C. 517 (1929).

39. Alan Wood Steel Co. v. A. G. S. Rr. Co., 190 I. C. C. 3, 13 (1932); H. Mrofiet Co. v. Southern Pacific Co., 195 I. C. C. 198, 200 (1933).

40. Salt Cases of 1923, 92 I. C. C. 388 (1924); Salt from Utah to San Francisco 61 I. C. C. 58 (1921); Coal from D. T. \& I. Rr. Mrines, 69 I. C. C. 112, 113 (1922).

41. Jefferson Island Salt Mining Co. v. United States, 6 F. (2d) 315 (N. D. Ohio 1925), sustaining Salt Cases of 1923,92 I. C. C. 388 (1924).

42. Coal from Illinois to Keokuk, Iowa, 210 I. C. C. 395 (1935); Gasoline from Sin Francisco Bay Points to Ogden, Utah, 198 I. C. C. 683 (1934), and see cases cited note 35 sufra.

43. This is specifically sanctioned in the Act, 36 STar. 544 (1910), 49 U. S. C. A. $₹ 1$ (6) (1926). 
can not be used at all without such a cost finding. ${ }^{44}$ But neither protesting carriers, nor the Commission, nor the Court itself in later cases, have taken so restricted a view of the minimum rate power. They have instead considered the argument that rates may be unlawful if they are enough below the prevailing structure in that territory on the commodity involved so as to threaten a disruption of that structure. ${ }^{45}$

Here the criteria are based upon what is thought to be reasonable for the other carriers. The consequence of the threatened reduction may be an undesirable diversion of the traffic from the lines now carrying it, possibly from a weak line to a strong one, or vice versa, ${ }^{40}$ or from a direct to a circuitous route; or it may be to provoke competitive reductions, which reduce carrier revenues all around-a rate war-and thus tend to force increases in other rates on the other lines if the reduction affects a major item of their traffic. ${ }^{47}$ When, as is often the case, the rates in the structure sought to be protected are regarded as reasonable maxima, the protested rate may still be well above the cost level, and the effort is therefore being made to fix the reasonable maxima as the measure of reasonable minima as well. This does violence to the usual conception of a minimum rate as lying at the lower limit of a "zone of reasonableness," and indicates that the real concern of the protestants is over rate relationships, normally a Section 3 question, or over the road's revenue from the general rate structure. But where the reduction is established by an independent carrier, the Ashland rule makes Section 3 inapplicable, and the solution of the problem then necessarily turns upon standards of reasonableness under Section 1.

Where rate relationships are the issue, the Commission has at times toyed with a doctrine of "relative unreasonableness." There is a legitimate scope for such a doctrine, in determining, solely by comparisons, the reasonableness of a particular and unimportant rate in an established structure, without stopping to inquire into the intrinsic reasonableness of the whole structure. ${ }^{48}$ But the temptation in using the doctrine is to compare the situations of the shippers, or of localities, rather than of the carriers, and thus make Section 1 do what the Ashland rule prevents Section 3 from accomplishing. Thus where the Commission is precluded

\footnotetext{
44. 289 U. S. 627 at 633 (1933).

45. See Youngstown Sheet \& Tube Co. v. United States, 295 U. S. 476 (1935).

46. Query, when is the maintenance and support of weak lines desirable? And in any event, what are "weak" lines?

47. Ex-River Coal to Cleveland, Lorain and other Ohio Points, 185 I. C. C. 211 (1932); Coal from Indiana to Illinois, 197 I. C. C. 245 (1933); 200 I. C. C. 609 (1934), rev'd United States v. Chicago, M., St. P. \& P. Rr. Co. 294 U. S. (1935); cf. Biklé, loc. cit. supra note 3.

48. Wyoming Coal Co. v. Virginian Ry., 96 I. C. C. 359 (1925), 98 I. C. C. 488 (1925), aff'd Virginian Ry. Co. v. United States, 272 U. S. 658 (1926); Chemical Line Co. v. Bellefonte Central Rr. Co., 147 I. C. C. 285 (1928).
} 
from finding that a given difference in rates offered by two carriers results in discrimination, it might nevertheless say that it is relatively unreasonable to give one group of shippers rates on a basis lower than that enjoyed by other shippers. This was what the Commission tried to do in the Lake Cargo cases. ${ }^{49}$ It is true that the effects of rate differentials on competing shippers, matters to which the Commission can hardly be blind, are essential elements in the proof of injury in discrimination cases. Yet to use them as grounds of action under Section 1 would lodge in the Commission a power of life and death over communities, to be exercised in the Commission's discretion, which sounds too much like national economic planning to be openly avowed. ${ }^{50}$ The doctrine of relative reasonableness has not been extended since the Lake Cargo cases ${ }^{61}$ and should be confined to comparisons of the effects of rate adjustments upon carriers, not upon shippers. Otherwise Section 3 becomes superfluous.

In judging a reduction by its effects on other carriers, the most important element is of course its effect upon their revenue. Since the enactment of Section 15a in 1920, the Commission has displayed an increasing solicitude for the financial well-being of the railroads. If the railroads still had a monopoly of the means of freight transportation, it might theoretically be possible for the Commission to adopt a consistent and scientific policy of controlling the total of railroad revenue by making horizontal changes in the general level of all rates as occasion required, leaving the adjustment of particular differentials to be settled by nonrevenue considerations. ${ }^{52}$ But no such simple task now confronts the

49. 139 I. C. C. 367 (1928). The Commission, after reducing the rates on coal from the northern fields and thereby ridening an established differential, undertook by an order under $\S 1$, to prevent a competitive reduction from the southern ficlds which would have restored the differential. The order was invalidated by a federal court on the grounds that there was no basis for action under $\S 3$, since the carriers involved were independent. And considered as an action under $\S 1$, the Commission had not relied upon transportation standards but had been actuated by a regard for the effect of the competitive reduction upon shippers in the northern fields, a criterion which it was stated the Commission could not lawfully apply. Anchor Coal Co. v. United States, 25 F. (2d) 462 (S. D. W. Va. 1928), rev'd on other grounds, United States v. Anchor Coal Co., 279 U. S. 812 (1929) (ATem).

50. Mansfield, The Hoch-Smith Resolution and the Consideration of Commercial Conditions in Rate Fixing (1931) 16 Corw. L. Q. 339. Shulman, Book Review (1936) 45 YALE L. J. 558; Comment (1931) 40 YaLE L. J. 600.

51. But cf. Third Es-River Case, 211 I. C. C. 1 (1935) discussed infro p. 1422.

52. This is to some degree the case. One may group together as "revenue" cases those in which no attention was paid to rate relationships, such as the horizontal changes considered in the Five Per Cent Case, 31 I. C. C. 351 (1914), 32 I. C. C. 325 (1914); Increased Rates, 1920, 58 I. C. C. 220 (1920); Reduced Rates, 1922, 68 I. C. C 676, 73 I. C. C. 189 (1922), 81 I. C. C. 170 (1923); The Fifteen Per cent Case, 1931, 178 I. C. C. 539 (1931), 179 I. C. C. 215 (1931), 191 I. C. C. 361 (1933); General Rate Level Investigation, 1933, 195 I. C. C. 5 (1933); Emergency Freight Charges, 1935, 208 I. C. C. 4 (1935), and the Passenger Fare case, 214 I. C. C. 174 (1936). See 3B Sharfman, op. cit. supro note 
Commission. The reductions offered by railroads are piecemeal changes, grudgingly given where the pinch is most felt, and generally in response to competition from sources outside the Commission's control. The effects of such reductions upon rail revenue must be considered in a similar piecemeal fashion.

How far may the Commission usefully and wisely go in preventing a rate reduction because of its revenue effect on neighboring carriers? That question is the key to an effective minimum rate policy. It is important at the outset to distinguish the source of the competition that compels the reduction. It may arise merely in the desire of the carrier proposing the reduction to get a larger share of the existing rail business. The authors of the Transportation Act, having this in mind, supposed that the minimum rate power would be needed to protect a weak carrier against low rates offered by a strong competitor for the purpose of putting the former out of business. Instances of such practice are not unknown. ${ }^{53}$ But the Commission's experience in attempting to conserve revenues demonstrates that strong lines more often ask for protection from the reckless competition of the weak. ${ }^{54}$ A rail line in receivership, or one having a circuitous route so that it normally gets but little of the traffic between two points, or an independent short line, may readily desire to cut rates, the only effect of which will be to reduce the revenues of the principal carriers without creating additional business. The Commission frowns on such reductions, ${ }^{55}$ although they would obviously bring cheaper transportation costs to shippers. And a minimum rate order to stop a reduction that does not go below the cost of the service is a subsidy to the status quo, the justification for which must

3, at 33-221. A much larger number of cases, of which Bituminous Coal to C. F. A. Territory, 46 I. C. C. 66 (1917) is typical, have dealt with comprehensive readjustments of rate relationships without attempting to alter the total revenue to be derived. The numerous investigations undertaken and readjustments ordered in Docket 17,000, in response to the Hoch-Smith Resolution of 1925, 43 STAT. 801 (1925), 49 U. S. C. A. \& 55 (1926) have attempted to do both. See the Commission's annual reports for summarics of actions taken.

53. United States v. Illinois Central Rr. Co., 263 U. S. 515 (1923), aff'g Swift Lumber Co. v. Fernwood \& Gulf Rr. Co., 61 I. C. C. 485 (1921).

54. It also demonstrates that there are other ways of conserving carrier revenues than by keeping the rate level high. But the unnecessary dissipation of carrier resources in concessions and allowances to large shippers, favoritism in purchases of materials, speculation in the stock of other carriers, etc., is irrelevant here except as it affects the wisdom or necessity of allowing the resultant losses to be taken out of the shippers. Sce the Commission proceedings in Ex parte 104, Practices Affecting Operating Revenue of Carricrs, 198 I. C. C. 134 (1933), 209 I. C. C. 11 (1935), 201 I. C. C. 323 (1934); Ann. Reps. I. C. C. 1933 , 29, id. 1934 at $24,26-28$, id. 1935 at 27 ; REPORTS of tae FederAL Coordinator of Transportation. See also Lowenthal, The Investor Pays (1933).

55. Coal from Illinois to Keokuk, Iowa, 210 I. C. C. 395 (1935); Jefferson City and North Jefferson, Mo., Rates, 213 I. C. C. 195 (1935). 
depend upon balancing the advantage to the shippers against the immediate necessities of the carriers.

Where the competition that compels the reduction comes from a source beyond the Commission's effective control, a graver question arises, and the wisdom of using the minimum rate power is much more doubtful. Such competition may come from highway vehicles, from waterways, or from private or wholly intrastate rail lines.0 The growth of trucking and the inroads it has made on freight traficic are too well known to require extended comment. Nor does the new Motor Carrier Act of 1935 promise to alter the situation materially. Although it purports to give the Commission power to fix minimum rates on common and contract carriers by motor, ${ }^{57}$ a power which might in theory be used to keep highway rates up near the rail level, this authority falls far short of the power necessary to an effective control of truck competition. In fact, these provisions do not seem capable of practical administration. If minimum rates for common or contract motor carriers are fixed substantially above their cost on any important items of truck trafic it may be predicted, with some confidence, that the shippers will truck their own goods as private carriers, not subject to regulation. 53 Waterways have developed in a similar if less spectacular manner. ${ }^{.9}$ When the Transportation Act was written, water borne traffic was confined largely to coastwise and Great Lakes shipping. Today, these facilities have expanded greatly, and in addition river navigation has been improved by the expenditure of vast sums, so that water transportation is available at many inland points. ${ }^{60}$ The only water carriers now subject to the Commission's jurisdiction are those controlled by railroads, mainly coastwise lines. Private or wholly intrastate railroads, exempted from control by the Interstate Commerce Act, are not numerous, but where they exist they may be safe against trunk line rail competition. Together, these alternative carriers by providing a definitely cheaper service have largely destroyed the monopoly position of the railroads, even in the carriage of heavy basic commodities, ${ }^{01}$ and promise more active competition in

56. It may come also from intrastate reductions imposed on interstate carriers by zealous state commissions. Unless effective truck competition is also present, such reductions are well within the Commission's control under $\$ 13$.

57. Motor Carrier ACT, 49 Stat. 559, 562, 49 U. S. C. A. $\S \S 316$ (e), 318 (b) (1935).

58. Another factor is the practical impossibility of federal policing of the rates actually paid to a multitude of contract carriers.

59. In $\S 500$ of the Transportation Act, the Commission was instructed not to prejudice water transportation by its policies. 41 SrAT. 499 (1920), 49 U. S. C. A. $\$ 142$ (1926).

60. It may be that one of the most important economic consequences of the TVA will be to force a reduction of rail rates by subsidizing water transportation.

61. Airplane transportation, important for consideration of passenger, mail, and some express service, threatens little damage to railroad freight trafic. 
the near future. ${ }^{62}$ Even now they have transformed many elaborately classified railroad tariff schedules into meaningless paper rates. ${ }^{03}$

The Commission thus faces an embarrassing dilemma when it considers issuing a minimum rate order on revenue grounds to protect the existing rail rate structure from unregulated competitors. If the order is issued, the rate structure may be preserved but the quantity of rail traffic will decline. There is little reason to believe that the shippers of the country as a whole will continue to use an expensive means of transportation when cheaper means are available. And there are no profits in paper rates. Hence the very purpose of the particular minimum order, to conserve the carrier revenues, is defeated. Moreover, the Commission in adopting such a course would only be postponing the inevitable process of readjustment to a lower price level in freight transportation similar to that which it is now forcing the railroads to undergo in a belated effort to recapture the passenger traffic of a decade ago. ${ }^{04}$ But on the other hand, if a minimum order is not issued, what becomes of the notion that the revenue needs of a group of carriers are a sufficient basis for preventing rate reductions by one of their number? Two recent cases illustrate the Commission's difficulties. In one, the reduction movement was started by an order of the Illinois Commerce Commission reducing intrastate rates on coal shipped to northeastern Illinois mines within the state. In a Thirteenth Section proceeding initiated by the Milwaukee railroad, which served the same consumers from Indiana coal districts, the Interstate Commerce Commission refused to restore the intrastate rates affected by the order of the Illinois Commission. ${ }^{06}$ Reductions to the same destinations from western Kentucky followed and were approved by the Commission. Thereupon the Milwaukee sought to restore the previous differentials by cutting its rates from Indiana, but the Commission called a halt. ${ }^{66}$ It found that the whole structure needed overhauling, that these piecemeal reductions endangered rail revenues, and it intimated that the Milwaukee had perhaps been enjoying too large a share of the business anyway. In Chicago, Milwaukee and St. Paul $R r$. Co. v. United States, ${ }^{67}$ this order drew a sharp rebuke from the Supreme Court, and it was held invalid for want of the findings necessary

62. $\$ 3$ causes the railroads to move slowly in offering reductions to meet this competition, since the reductions must usually be generalized to avoid discrimination.

63. As an illustration of paper rates on which no traffic moves, a single freight car daily each way now carries all the less-than-carload freight handled by the New Haven Railroad between New York and Boston. Yet pages and pages of filed tariffs of the rond are devoted to rates on minutely classified 1. c. l. traffic.

64. Passenger Fare case, 214 I. C. C. 174 (1936), 215 I. C. C. 350 (1936).

65. Intrastate Rates on Bituminous Coal in Illinois, 182 I. C. C. 537 (1932).

66. Coal from Indiana to Ilinois, 197 I. C. C. 245 (1933), 200 I. C C. 609 (1934).

67. 294 U. S. 499 (1935). 
to support it. The Court pointed out that the Commission had not found either that the rates were non-compensatory, or that they jeopardized the carrier's capacity for service. The Commission had decided, as Mr. Justice Cardozo put it, that: ${ }^{\mathrm{cs}}$

"The schedules are to be congealed as they exist, because if not congealed they will be fluid, fluidity is change, and change has the potency, if not the promise, of disturbance ... this and hardly more is the teaching of the report."

In answer, he said: ${ }^{69}$

"Every change of a rate schedule, either voluntary or involuntary, is a disruption pro tanto of the rate structure theretofore prevailing. Plainly such a disruption without more is no sufficient reason for prohibiting a change."

It is not clear, however, whether this decision was intended merely to tighten up Commission procedure, or to define the criteria of unreasonableness warranting a minimum order. If the court aimed merely at the first objective, the case is not significant for this discussion, except to the degree that it may compel the Commission in the future to be more precise in stating what statutory grounds it is invoking in minimum rate cases. If, however, the court was attempting to formulate standards for the exercise of the minimum rate power, it seemed to announce a doctrine that the Court itself was unwilling to follow a few months later in the Youngstown case. In the Milwaukee case, the court said: ${ }^{70}$

"There is no suggestion in the report that the rates have been so reduced as to be less than compensatory ... they do not pass the minima beyond which charges are too low. A zone of reasonableness exists between maxima and minima within which a carrier is ordinarily free to adjust its charges for itself."

The Youngstown case is more instructive. It arose out of a longstanding controversy between western Pennsylvania coal operators and their trunk line carriers over the movement of coal in the Pittsburgh district. ${ }^{71}$ In 1927 the Pittsburgh, Lisbon \& Western Railroad, a short interurban, south of Youngstown, controlled indirectly by the Pittsburgh Coal Company, asked the Commission for a certificate of public convenience and necessity to construct two branches, one north to Youngstown and the other south to the Ohio River, to permit the movement of coal from river mines in the Pittsburgh district by barge and rail to Youngstown. The Lisbon suggested a rate of 77 cents for its rail haul
68. Id., at 508 .
69. Id., at 507.

70. Id. at 505, ciling the Texas \& Pacific and Illinois Central cases, stpra notes 30 and 53.

71. Some of the details of this struggle are related in Mirisfirid, The Lame Carco Co.1L RATE CONTROVERSX (1932) 39-40. 
by the new route; ${ }^{72}$ the river phase of the trip promised to cost not more than 25 or 30 cents a ton. The application was of course opposed by the trunk lines which carried coal all-rail from Pittsburgh to Youngstown at $\$ 1.34$ a ton. The Commission found that a river-rail route was justified, and at the rate proposed, but denied the Lisbon's application on the ground that the trunk lines could provide a similar service at less capital and operating cost by constructing transfer facilities at the points where they cross the river. ${ }^{73}$ These lines responded by proposing a rate of $\$ 1.02$ for the rail part of the contemplated route, which was suspended by the Commission in the First Ex-river case and cancelled as unreasonably high, without prejudice to the establishment of a rate of 77 cents. ${ }^{74}$ The lower rate was not put into effect by the carriers until two years later, after the Wheeling and Lake Erie, an independent line, had published ex-river rates at a still lower level to points beyond Youngstown. The Wheeling and Lake Erie's rates were raised by the Commission in the Second Ex-river case, ${ }^{75}$ to 77 cents plus the usual destination differentials between Youngstown and the points involved, indicating a continued reliance on that rate as reasonable. The Lisbon, however, proceeded with its extensions on the theory that it was an intrastate carrier without the Commission's jurisdiction. ${ }^{70}$ In the meantime, the Ohio Commission inaugurated a series of reductions on intrastate coal movements. These were finally restored to the previous level in a Thirteenth Section proceeding, ${ }^{77}$ and on the same day the Ex-River cases were reopened, leading to a third decision which raised the previous maximum reasonable rate of 77 cents to a minimum reasonable rate of 90 cents to Youngstown-almost to the all-rail scale. ${ }^{78}$ The new rates were not defended at all on the basis of $\operatorname{cost}_{,}{ }^{70}$ but quite frankly as

72. It estimated that the costs for this haul are between 50 and 60 cents per ton.

73. Construction of Branches by Pittsburgh, Lisbon \& Western Rr. Co., 150 I. C. C. 43 (1928); 150 I. C. C. 619 (1929). As a negative order, it was not judicially roviewable, Piedmont \& Northern Ry. Co. v. United States, 280 U. S. 469 (1930).

74. Coal, Bituminous, Ex-River, from Colona and Conway, Pa. to Youngstown, Ohio, 163 I. C. C. 3 (1930). For the distance of 43 miles, ton mile earnings would amount to 23.7 mills on the rate of a $\$ 1.02$, and to 17.9 mills for the 77 -cent rate. Either of these earning figures is very high for movements of coal in substantial volume.

75. Ex-River Coal to Ohio Points, 185 I. C. C. 211 (1932).

76. Part of the construction was done by the Youngstown \& Suburban Rr. Co., an interurban not subject to the Commission's jurisdiction, which, with the Lisbon, was controlled by the Pittsburgh Coal Co. Cf. Youngstown and Suburban Ry. Co., Operation, Fin. Docket 8928, 175 I. C. C. 699 (1931).

77. Intrastate Rates on Bituminous Coal within Ohio, 192 I. C. C. 413 (1933), subsequently sustained in Ohio v. United States, 292 U. S. 498 (1934). The original order was modified, 192 I. C. C. 734 (1933), 203 I. C. C. 411 (1934), 208 I. C. C. 671 (1935).

78. Coal, Bituminous, Ex-River from Colona and Conway, Pa., to Youngstown, 197 I. C. C. 617 (Third Report) (1933).

79. Despite the Supreme Court's assumption to the contrary in its decision of the case. 
relatively reasonable and necessary to protect the all-rail rate structure. There was also a finding of discrimination as between originating mines at river points and inland, but as appeared later, this was a make-weight argument. The Supreme Court nevertheless upheld the Commission in a brief opinion, against the contentions that the findings were insufficient and unsupported by evidence. ${ }^{80}$

It is difficult to reconcile this decision with the Court's dictum in the Texas and Pacific case, or with the decision in the Miliwaukec case. It is possible to dismiss the former as being simply dictum. The latter can be distinguished by arguing that it actually held nothing as to the substantive grounds for a minimum rate order but dealt with the form of Commission procedure; or by saying that in the Youngstown case the Court took seriously the ground of discrimination which it ignored in the Milwaukee case. In any event the Court in the Youngstown case supported the Commission in wiping out any "zone of reasonableness" between maximum and minimum rates. What was attempted here, in effect, was to freeze the structure at the all-rail level, to assimilate the cheaper ex-river route to the higher-cost rate structure. Evidently the Commission at first defined reasonableness in terms of the differences in cost, and then, out of concern for trunk line revenues, changed its mind and defined it relatively in terms of the existing all-rail structure. ${ }^{88 \mathrm{a}}$ In order to protect the all rail revenue, the Commission changed its earlier attitude toward the fact that the barge-rail route offered a definitely cheaper service, the benefits of which, it then thought, ought to be passed along to the shippers. The sequel brings into sharp relief the difficulties inherent in fixing minimum rates above cost. Two uncontrolled competitors have appeared. The first is trucking. When the surcharge imposed by Emergency Freight Charges, $1935^{81}$ was applied to the ex-river as well as to the all-rail rate, the Youngstown Sheet \& Tube Co. confronted the trunk line carriers with a contract for the hauling of ex-river coal, offered for signature by a trucking concern, which the shipper proposed to accept unless the surcharge was removed. The carriers capitulated. Although the removal of the surcharge would not violate the minimum

See Brief for Appellants 29, 30, Youngstown Sheet and Tube Co. v. United States, 295 U. S. 476 (1935).

So. Youngstown Sheet \& Tube Co. v. United States, 295 U. S. 476 (1935). The opinion of the three-judge court sustaining the Commission's order is reported in $7 \mathrm{~F}$. Supp. 33 (N. D. Ohio 1934). The merits were not seriously considered and most of the opinion was devoted to the right of the shippers to appeal from the Commission's order. Cf. Skinner \& Eddy Corp. v. United States, 249 U. S. 557 (1919).

80a. Note that in the Second Ex-River case, supra note 75, where the proposed reductions were more drastic, the commission used the 77th ex-river rate to Younstown (supposedly a maximum rate, but lower than the all-rail rate) as the bacis for the minimum rate there fixed.

81. 208 I. C. C. 4 (1935). 
order which had been established before the surcharge was applied, it did spread the differential between the ex-river and all-rail rates which had been fixed by the Commission in the Third Ex-River case, on the basis of alleged discrimination existing as between the river and inland lines. The trunk lines appealed to the Commission and it withdrew the finding of discrimination upon which the Court's approval of the minimum order had in part rested. ${ }^{82}$ Thus by eating its own words hastily and unceremoniously the Commission staved off for the time being the threat of barge-truck carriage to the all-rail traffic in western Pennsylvania coal.

It was less successful in averting competition from the second service. The Lisbon route was constructed, as has been said, without the Commission's approval. The Pittsburgh Coal Company now takes coal from its river mines to the Ohio shore by barge, and then by its own private railroad to a washing plant six miles inland. There it is sold and its transportation to Youngstown via the Lisbon, an intrastate common carrier subject only to the Ohio Commission, begins. The Supreme Court has just sanctioned the arrangement as outside the jurisdiction allowed the Interstate Commerce Commission by the Transportation Act, ${ }^{\mathrm{ga}}$ over the protest of the trunk lines that this maneuvering is all part of a single interstate movement. Moreover, the Court sustained the Ohio Commission's control of the terms upon which the trunk lines must switch the Lisbon's cars over their tracks upon arrival in Youngstown. ${ }^{84}$ No figures on the cost of the movement from the mines to the washing plant are available, but they are evidently low, and for the rest of the haul the rates are controlled by a commission that is not interested in maintaining the all-rail rate structure in Ohio at its present level. In a further attempt to bring this route under its control, the Interstate Commerce Commission at the request of the trunk lines has just announced an investigation of the Lisbon under the commodities clause, ${ }^{85}$ but the decision of the Supreme Court at the end of the present term in United States v. Elgin, Joliet \& Eastern Ry. Co ${ }^{86}$ would seem to block that approach as well. Thus to the extent that Youngstown consumers care

82. Coal, Bituminous, Ex-River, from Colona and Conway, Pa. to Youngstown, Ohio, 211 I. C. C. 1 (1935).

83. Pennsylvania Rr. Co. v. Public Utilities Commission of Ohio, 3 U. S. L. Week, April 28,1936 , at 827 , col. 1 .

84. Ibid.

85. New York Times, May 19, 1936, at 33, col. 7. On charges by the trunk lino railroads of violations of the "commodities clause," [34 StaT. 585 (1906), 49 U. S. C. A. \& 1 (8) (1926)] and of discrimination, the Commission has ordered an investigation of the practices of the Youngstown and Suburban, the Pittsburgh, Lisbon \& Western, and the Montour Railroads, all controlled by the Pittsburgh Coal Co., which in turn is dominated by Mellon interests. Docket No. 27402, with which Fin. Docket 8928 was consolidated for rehearing, beginning June $22,1936$.

86. 3 U. S. L. Week, May 26, 1936, at 991, col. 3. 
to rely on the largest coal operator in Pittsburgh for their supply, they need pay neither the all-rail nor the ex-river trunk line rates. It seems unlikely therefore that the Commission's solicitous protection of the all-rail rate structure in Ohio can be indefinitely continued.

The discussion suggests two general inferences by way of conclusion. First, the Commission may use the several phases of its minimum rate power to cure discrimination, especially by fixing differentials. The gap in this field established by the Ashland rule remains unchanged by the enactment of the minimum rate power, and limits the Commission's action to cases where carriers can be held individually responsible. But all the recognized categories of rate discrimination are within the scope of the minimum rate power. Second, in basing a minimum order on a finding that a rate is unreasonably low, the Commission has adopted, and the Supreme Court has sanctioned, criteria that go beyond what can be safely used in practice. The Commission may properly act to prevent rate reductions below cost, either to the carrier that initiates them or in some circumstances to its rail competitors; or reductions which result merely in an uneconomic diversion of traffic from one line to another; or which threaten a too sudden and drastic, or ill-distributed loss of revenue to a group of carriers. The cost of service is a standard acceptable if not precise; service below it can hardly fail to be at the expense of stockholders or, more likely, of other traffic. But the Commission is on dangerous ground in fixing minimum rates substantially above cost, for no other reason than the protection of a given rate structure. Such action is a public recognition of a vested right in particular carriers to the traffic involved, which the Commission cannot enforce as against other than interstate railroads nor easily justify on grounds of policy. It is a public subsidy of those carriers and an invitation to cheaper, unregulated carriers to help themselves to another slice of the railroad cake. A cheaper cost of railroad service and a progressively cheaper price for it to shippers, is a sounder answer to carrier competition than a minimum rate order. 